\title{
PENINGKATAN KOMPETENSI PENYUSUNAN RPP MELALUI TINDAKAN IHT (IN HOUSE TRAINING) BAGI GURU SMAN 7 KERINCI TAHUN PELAJARAN 2017/2018
}

\author{
BENTONI \\ Kepala SMA Negeri 7 Kerinci Provinsi Jambi \\ Email : Bentoni793@gmail.co.id
}

\begin{abstract}
ABSTRAK
Penelitian ini bertujuan untuk: 1) mengetahui peningkatan kompetensi guru dalam menyusun Rencana Pelaksanaan Pembelajaran (RPP) melalui tindakan In House Training (IHT) di SMA Negeri 7 Kerinci Provinsi Jambi. 2) mengetahui langkah peningkatan kompetensi guru dalam menyusun RPP dengan melaksanakan IHT di SMA Negeri 7 Kerinci. Penelitian ini merupakan Penelitian Tindakan Sekolah (PTS) terdiri dari 2 siklus. Subyek penelitian ini adalah guru SMA Negeri 7 Kabupaten Kerinci sebanyak 36 dari 39 guru yang ada, baik PNS maupun Honorer. setiap siklus meliputi tahap perencanaan, pelaksanaan, observasi, dan refleksi. Teknik analisis data yang digunakan adalah deskriptif komparatif. Dari hasil penelitian dapat disimpulkan bahwa: 1) IHT dapat meningkatkan kompetensi guru SMA Negeri 7 Kerinci dalam menyusun RPP. Hal ini ditunjukkan dengan meningkatnya ketercapaian kompetensi guru dari sebesar 65,50 pada kondisi awal, menjadi sebesar 73,25 pada akhir tindakan Siklus 1, dan meningkat menjadi 82,25 pada tindakan Siklus II. 2) Langkah-langkah pelaksanaan IHT guna meningkatkan kompetensi profesional guru dalam Menyusun RPP di SMA Negeri 7 Kerinci sebagai berikut: (a) Sosialisasi tindakan IHT mengenai penyusunan RPP bagi guru; (b) Mempersiapkan materi bimbingan berupa pelaksanaan pembelajaran disertai simulasinya; (c) Mempersiapkan instrumen IHT; (d) Melaksanakan tindakan IHT; dan e) Melaksanakan pengamatan di kelas saat dilaksanakan tindakan pembelajaran oleh guru.
\end{abstract}

Kata Kunci:kompetensi guru, penyusunan RPP, in house training.

\section{PENDAHULUAN}

Peran guru dalam mentransformasikan input-input pendidikan sangat penting. Hal ini tidak terlepas dari adanya sistem persekolahan yang mencakup input - proses - output, di mana guru sebagai salah satu faktor input yang berperan penting dalam proses untuk dapat menghasilkan output sesuai dengan apa yang diharapkan.

Agar dapat melaksanakan proses yang berkualitas, guru dituntut untuk melaksanakan tugasnya sesuai dengan standar kerja guru yang telah ditetapkan. Pasal 35 ayat (1) UU No. 14/ 2005 menyebutkan bahwa beban kerja guru mencakup tindakan pokok yaitu merencanakan pembelajaran, melaksanakan pembelajaran, menilai hasil pembelajaran, membimbing dan melatih peserta didik, serta melaksanakan tugas tambahan.

Amanat yang terkandung dalam pasal tersebut mengimplikasikan bahwa sebenarnya ada lima tuga pokok yang harus dilaksanakan oleh guru. Akan tetapi, dari kelima tugas pokok tersebut hanya ada tiga jenis tugas yang berupa tindakan tatap muka, yaitu melaksanakan pembelajaran, menilai hasil pembelajaran, serta membimbing dan melatih peserta didik. Sedangkan tugas perencanaan pembelajaran yang merupakan salah satu tugas pokok sering terabaikan karena tidak berkaitan dengan tatap muka.

Kemampuan menyusun Rencana Pelaksanaan Pembelajaran bagi seorang guru sangat penting, karena dengan perencanaan yang baik, matang dan terarah dapat menentukan keberhasilan pembelajaran. Standar Proses, perencanaan proses pembelajaran meliputi Silabus dan Rencana Pelaksanaan Pembelajaran (RPP). RPP tersebut merupakan pedoman dan acuan dalam pelaksankan pembelajaran. Hasil pembelajaran sangat ditentukan oleh kualitas RPP yang disusun oleh guru. Oleh karena itu guru harus memiliki kemampuan menyusun RPP secara baik. RPP yang baik adalah RPP yang sesuai dengan Permendiknas Nomor 22 tahun 2016. Karena, tidak selamanya perencanaan yang dibuat bisa berjalan sebagaimana mestinya sesuai 
dengan yang direncanakan apabila perencanaan tersebut tidak memiliki standar yang ditetapkan (Subekti, 2019).

Hal terpenting dalam suksesnya pembelajaran adalah guru mampu merencanakan pembelajaran dengan baik dan benar sesuai kebutuhan pembelajaran. Guru harus memahami dengan baik akan apa yang harus dilakukannya dalam melaksanakan tugas dan tanggung jawabnya sebagai guru di bidang pendidikan. Ada tiga tugas utama yang harus dilakukan oleh guru yakni (a) merencanakan pembelajaran, (b) melaksanakan pembelajaran, dan (c) menilai pembelajaran. Dari ketiga tugas utama yang harus dilakukan guru tersebut perencanaan pembelajaran memainkan peranan yang sangat vital karena pelaksanaan dan penilaian pembelajaran akan terlaksana dengan baik apabila guru mampu membuat perencanaan pembelajaran dengan baik. Sebaliknya seorang guru akan gagal melaksanakan pelaksanaan dan penilaian pembelajaran terhadap peserta didik jika tidak direncana dengan baik (Maolana, 2018).

Karena begitu pentingnya perencanaan tersebut, maka hal tersebut harus dikuasai oleh para guru. Seperti diketahui bahwa perencanaan pembelajaran terdiri dari beberapa unsur yakni tindakan mengkaji kurikulum, menyusun silabus, strategi pembelajaran, sumber belajar yang digunakan dan satuan tindakan pembelajaran. Akan tetapi pada kenyataannya sering dijumpai guru sering abai dalam menyusun perencanaan pembelajaran dengan benar. Alasan yang sering ditemukan dikarenakan para guru merasa dengan mudah meniru dokumen berupa RPP dari teman sejawat. Hal tersebut dikarenakan jarangnya para guru untuk mencari tahu dan meningkatkan kompetensi dalam penyusunan RPP. Akibatnya sering ditemukan bentuk RPP yang tidak sesuai dengan kebutuhan pembelajaran di sekolah. Dengan demikian, perencanaan pembelajaran banyak tergantung kepada kompetensi guru mengembangkannya, karena tugas guru berkaitan dengan melaksanakan pembelajaran yang menjadi tanggungjawabnya. Oleh karena itu, diperlukan perencanaan pembelajaran yang dapat mencapai keefektifan pembelajaran yang dilaksanakan (Agustiani, 2018).

Fenomena tersebut dialami pula oleh guru di SMA Negeri 7 Kerinci. Masih ditemukan sebagian guru melakukan tindakan menduplikat atau mengkopi penyusunan perencanaan pembelajaran dari satuan pendidikan yang lain. Tindakan tersebut berakibat pada guru menjadi kurang memahami kebutuhan sekolah, sehingga ditemukan banyak sekali ketidaksesuaian perencanaan yang dibuat dengan pelaksanaan proses pembelajaran di kelas. Keadaan yang kurang menggembirakan tersebut didukung oleh hasil penilaian pada tiga aspek kinerja guru yang meliputi perencanaan pembelajaran, pelaksanaan pembelajaran, dan penilaian pembelajaran. Hasil penilaian menunjukkan bahwa perencanaan pembelajaran yang disusun oleh para guru sudah baik yang ditunjukkan dengan rata-rata skor sebesar 35.38 dari skor ideal sebesar 50 atau dengan tingkat ketercapaian kinerja rata-rata sebesar $70.75 \%$.

Hasil penilaian pada aspek perencanaan pembelajaran yang sudah baik tersebut ternyata tidak ditunjang dengan kompetensi yang sebanding dalam pelaksanaan. Hal ini ditunjukkan dengan hasil penilaian pada aspek pelaksanaan di mana diperoleh skor rata-rata sebesar 64.75 dari skor ideal sebesar 100 atau dengan tingkat ketercapaian kompetensi sebesar 64.75\%.Penilaian pada aspek kompetensi guru dalam penilaian juga tidak mencerminkan tingginya kemampuan guru dalam kemampuan penyusunan perencanaan pembelajaran. Hal ini ditunjukkan dengan hasil penilaian pada aspek penilaian di mana diperoleh skor rata-rata sebesar 70.38 dari skor ideal sebesar 110 atau dengan tingkat ketercapaian kompetensi sebesar $63.98 \%$. Secara keseluruhan, hasil penilaian kompetensi guru pada ketiga aspek penilaian kompetensi guru SMA Negeri 7 Kerinci masih belum optimal. Hal ini ditunjukkan dengan skor rata-rata yang diperoleh baru mencapai 170.5 dari skor ideal sebesar 260 atau dengan tingkat ketercapaian kompetensi sebesar $65.58 \%$. Kondisi tersebut perlu menjadi perhatian bagi Kepala Sekolah untuk melakukan tindakan perbaikan. Tindakan perbaikan yang dapat dilakukan Kepala Sekolah adalah melalui tindakan IHT.

Bahwa pelatihan merupakan upaya untuk meningkatkan pengetahuan, mengubah perilaku dan mengembangkan keterampilan. (Sa'bani, 2017). Salah satu bentuk pelatihan 
tersebut yaitu dalam bentuk kegiatan In House Training (IHT). In House Training (IHT) merupakan program yang diselengarakan di sekolah atau tempat lain menggunakan peralatan dan materi yang relevan dengan permasalahan yang dihadapi, tujuannya adalah untuk mengembangkan kompetensi berupa skill, knowledge, dan attitude (Basri dan Rusdiana, 2021: 15). Pengertian In House Training (IHT) adalah sebuah program pendidikan tunggal, untuk mengajarkan atau memperkenalkan pada setiap peserta dengan keterampilan praktis, teknis, atau ide-ide yang bisa digunakan pada pekerjaan mereka di kehidupan sehari-hari mereka. Pada umumnya In House Training (IHT) yang baik memiliki kapasitas yang kecil, yang terdiri dari 6-15 orang agar lebih fokus. In House Training (IHT) biasanya dibuat untuk orang-orang yang mempunyai minat yang sama, atau bekerja di dalam bidang yang sama. Kegiatan ini biasanya diisi oleh para pakar atau orang yang telah mempunyai banyak pengalaman, di dunia nyata (Jamaludin, 2020).

Berdasarkan latar belakang permasalahan tersebut di atas, peneliti tertarik untuk melakukan penelitian tindakan yang berkaitan dengan optimalisasi peran Kepala Sekolah dalam meningkatkan kompetensi guru. Adapun judul yang diangkat dalam penelitian ini adalah "Peningkatan Kompetensi Guru dalam Menyusun RPP melalui Tindakan IHT (In House Training) di SMA Negeri 7 Kerinci.

In-House Training merupakan pelatihan yang terjadi atas permintaan suatu komunitas tertentu apakah itu lembaga profit ataupun nonprofit. Istilah In-House Training sama pengertiannya dengan in-servis training menurut Hadari Nawawi (1983:113) yang dikutip oleh Dadang Dahlan menyatakan in-servis training sebagai usaha untuk meningkatkan pengetahuan dan keterampilan guru dalam bidang tertentu sesuai dengan tugasnya agar dapat meningkatkan efisiensi dan produktivitas dalam bidang tersebut. Lebih lanjut dikemukakan bahwa program in-servis training ini diperlukan karena banyak guru-guru muda yang belum mendapat pengalaman dan bekal yang cukup dalam menghadapi pekerjaannya. Agar program in-servis training ini efektif memerlukan manajemen pelatihan seperti dikemukakan Gaffar (1993) yang dikutip oleh Dadang Dahlan pengembangan mutu sumber daya manusia memerlukan manajemen yang secara logis perlu mengikuti tahapan need assesment, merumuskan tujuan dan sasaran, mengembangkan program, menyusun action plan, melaksanakan program, monitoring dan supervise serta evaluasi program.

\section{METODE PENELITIAN}

Metode penelitian yang digunakan adalah penelitian tindakan sekolah (PTS), dengan pendekatan kualititatif dengan menyajikan data hasil penelitian secara deskriftif berupa pemaparan dari data diteliti dengan membandingkan kondisi sebelum tindakan dengan setelah tindakan dilaksanakan. Selanjutnya data yang dipaparkan berupa langkah dari pelaksanaan IHT dalam meningkatkan kompetensi guru.

Dalam penelitian ini teknik pengumpulan data yang dipergunakan adalah dengan melakukan observasi terhadap kegiatan guru dalam menyusun RPP, dan melakukan wawancara dengan guru dalam membahas masalah-masalah yang dialami oleh guru dan tentang tanggapan guru terhadap pelaksanaan IHT dalam penyusunan RPP.

Instru men penilaian yang digunakan adalah lembar wawancara dan lembar observasi untuk penilaian penyusunan RPP berdasarkan pada kelengkapan komponen-komponen RPP menurut Permendikbud No 22 tahun 2016 tentang Standar Proses dalam persiapan perencanaan pelaksanaan pembelajaran. Penelitian ini dilaksanakan di SMA Negeri 7 Kerinci dengan alamat Lindung Jaya, KayuAro, Kabupaten Kerinci Provinsi Jambi. Dalam pelaksanaan penelitian tindakan sekolah yang menjadi subjek adalah guru mata pelajaran sebanyak 36 orang. Penelitian ini dilaksanakan selama 3 bulan yakni dari bulan Januari-April 2018.

\section{HASIL DAN PEMBAHASAN}

Peran guru dalam mentransformasikan input-input pendidikan sangat penting. Hal ini tidak terlepas dari adanya sistem persekolahan yang mencakup input-proses-output, di mana 
guru sebagai salah satu faktor input yang berperan penting dalam proses untuk dapat menghasilkan output sesuai dengan apa yang diharapkan, beberapa guru di SMA Negeri 7 Kerinci masih banyak yang belum memiliki kompetensi dalam menyusun RPP. Berikut rekap hasil penilaian kualitas RPP pada kondisi awal.

Tabel 1. Hasil Penilaian Kualitas RPP Kondisi Awal

\begin{tabular}{ccccc}
\hline TingkatKompetensi & Kategori & Frekuensi & Presen-tase & Rata-Rata \\
\hline $85-100 \%$ & Sangatbaik & 6 & $16,67 \%$ & $2502,5: 36=69,51$ \\
$75-85 \%$ & Baik & 11 & $30,55 \%$ & \\
$65-75 \%$ & Cukup & 6 & $16,67 \%$ & Kategori Cukup \\
$<65 \%$ & Kurang & 13 & $36,11 \%$ & \\
\hline & JUMLAH & & 36 & $100 \%$ \\
\hline
\end{tabular}

Tabel 2. Hasil Pengamatan Guru dalam Menyusun RPP Kondisi Awal

\begin{tabular}{lllll}
\hline TingkatKompetensi & Kategori & Frekuensi & $\%$ & Rata-Rata \\
\hline $85-100 \%$ & Sangatbaik & 10 & $27,77 \%$ & $2507,5: 36$ \\
$75-85 \%$ & Baik & 0 & $0 \%$ & $=69,58$ \\
$65-75 \%$ & Cukup & 15 & $41,66 \%$ & Kategori \\
$<65 \%$ & Kurang & 11 & $30,55 \%$ & Cukup \\
\hline JUMLAH & & & 36 & \\
\hline
\end{tabular}

Siklus I

Perencanaan adalah langkah awal yang dilakukan oleh penulis saat akan memulai tindakan. Agar perencanaan mudah dipahami dan dilaksanakan oleh penulis yang akan melakukan tindakan, maka penulis membuat rencana tindakan diantaranya Peneliti merencanakan waktu, sasaran, dan cara mengobservasi selama proses IHT, merencanakan metode IHT dan perencanaan tindak lanjut. Observer atau pengamat yang dilibatkan dalam penelitian diambil dari rekan sejawat. Pemilihan dua observer berbeda dimaksudkan agar data yang diperoleh reprensentatif. Peneliti juga mempersiapkan instrumen hasil IHT, kemudian menganalisis hasil IHT tersebut. Perencanaan dilakukan kurang lebih 1 minggu. Tidak ada kendala yang berarti yang dihadapi peneliti selama menyusun perencanaan tindakan sekolah ini.

Pelaksanaan pada Siklus I dilakukan dalam tiga pertemuan. Dalam pelaksanaan ini melibatkan 36 orang guru yang diobservasi. Tindakan pertama pada bulan Februari 2018, seluruh guru dikumpulkan dalam satu ruangan kemudian diberikan IHT terutama dalam penguasaan menyusun Rencana Pelaksanaan Pembelajaran (RPP). Pembinaan ditekankan pada proses penyusunan RPP baik dari materi maupun media yang akan digunakan oleh guru dalam mengajar, guru dibimbing untuk menyusun RPP dengan benar. Selain itu guru juga dibimbing dalam menggunakan dan pemanfaatan sumber dan media belajar. Selama pelaksanaan, observer mengamati jalannya kegiatan.

Setelah melakukan serangkaian kegiatan IHT pada masing-masing guru kemudian guru diberi kesempatan untuk membuat RPP sesuai dengan pengarahan yang telah diberikan, setelah selesai guru diberikan kusioner untuk diisi. Lembar kuesioner dan RPP yang telah diisi dianalisis. Kegiatan ini dilaksanakan pada Februari s.d Maret 2018. Tidak ada kendala yang berarti yang dihadapi peneliti selama proses pelaksanaan ini.

Observasi dilakukan oleh peneliti dengan menggunakan lembar observasi selama satu bulan (satu siklus), untuk semua guru yang berjumlah 36 orang. Selama melakukan serangkaian kegiatan IHT, guru masih banyak yang terlihat malas- malasan dalam mengikuti kegiatan IHT. Rekapitulasi hasil observasi guru dalam menyusun RPP pada siklus I dapat dilihat pada Tabel 3. 
Tabel 3. Hasil Pengamatan Guru dalam Menyusun RPP Siklus I

\begin{tabular}{ccccc}
\hline TingkatKompetensi & Kategori & Frekuensi & $\%$ & Rata-Rata \\
\hline $85-100 \%$ & Sangatbaik & 3 & $8,33 \%$ & $2550: 36$ \\
$75-85 \%$ & Baik & 12 & $33,33 \%$ & $=70,83$ \\
$65-75 \%$ & Cukup & 12 & $33,33 \%$ & Kategori \\
$<65 \%$ & Kurang & 9 & $25 \%$ & Cukup \\
\hline & JUMLAH & & 36 & $100 \%$ \\
\hline
\end{tabular}

Berdasarkan Tabel 3 dapat dilihat bahwa hasil observasi guru pada saat menyusun RPP pada siklus I, rata-rata yang diperoleh sebesar 70,83 dengan kategori cukup.Rekapitulasi hasil penilaian kualitas RPP pada siklus I dapat dilihat pada Tabel 4.

Tabel 4. Hasil Penilaian Kualitas RPP Siklus I

\begin{tabular}{ccccc}
\hline TingkatKompetensi & Kategori & Frekuensi & $\%$ & Rata-Rata \\
\hline $85-100 \%$ & Sangatbaik & 0 & $0 \%$ & $2692,5: 36$ \\
$75-85 \%$ & Baik & 24 & $66,66 \%$ & $=74,79$ \\
$65-75 \%$ & Cukup & 9 & $25 \%$ & Kategori \\
$<65 \%$ & Kurang & 3 & $8,33 \%$ & Cukup \\
\hline & JUMLAH & & 36 & $100 \%$
\end{tabular}

Berdasarkan Tabel 4 dapat dilihat bahwa rata-rata nilai kualitas RPP yang dibuat oleh guru pada siklus I sebesar 74,79 yang termasuk kategori cukup.

Tahap Refleksi yaitu menganalisis hasil pengamatan, dan megevaluasi kegiatan IHT yang baru saja dilaksanakan. Refleksi dilakukan untuk mengetahui kekurangan atau kendala pada siklus I, sehingga dapat diperoleh kesimpulan tentang bagian yang perlu diperbaiki dan bagian yang telah mencapai tujuan penelitian. Pelaksanaan IHT bagi guru untuk meningkatkan kompetensi guru dalam menyusun RPP pada siklus I dapat dikatakan cukup baik namun masih ada beberapa kendala, yaitu: a) Guru masih banyak yang belum paham tentang penyusunan RPP yang benar. b) Partisipasi guru dalam kegiatan IHT masih belum terlihat, masih banyak guru yang enggan bertanya pada supervisor. c) Ketika guru diberi tugas untuk menyusun RPP, guru enggan untuk mengerjakan.

\section{Siklus II}

Tindakan siklus II merupakan upaya perbaikan terhadap tindakan siklus I. Tahapan yang dilakukan sama dengan tahapan pada siklus I, namun pada siklus II ada beberapa hal yang perlu ditekankan dan ditambahkan, yaitu: Pertama, sebelum melaksanakan IHT, supervisor menekankan agar guru lebih berperan aktif dalam kegiatan IHT agar kemampuan guru dalam menyusun RPP dapat meningkat, Kedua, supervisor memberitahukan kepada guru bahwa guru tidak usah enggan untuk bertanya apabila ada sesuatu yang belum dipahami tentang menyusun RPP.

Melaksanakan kegiatan sesuai dengan perencanaan tindakan siklus II. Dalam pelaksanaan ini melibatkan 36 orang guru yang diobservasi. Tindakan pertama pada bulan Maret 2018, seluruh guru dikumpulkan dalam satu ruangan kemudian diberikan IHT terutama dalam penguasaan menyusun Rencana Pelaksanaan Pembelajaran (RPP). Pembinaan ditekankan pada proses penyusunan RPP baik dari materi maupun media yang akan digunakan oleh guru dalam mengajar, guru dibimbing untuk menyusun RPP dengan benar. Selain itu guru juga dibimbing dalam menggunakan dan pemanfaatan sumber dan media belajar. Selama pelaksanaan, observer mengamati jalannya kegiatan IHT.

Setelah melakukan serangkaian kegiatan IHT pada masing-masing guru kemudian guru diberi kesempatan untuk membuat RPP sesuai dengan pengarahan yang telah diberikan, setelah selesai guru diberikan kusioner untuk diisi. Lembar kuesioner dan RPP yang telah diisi dianalisis. Kegiatan ini dilaksanakan pada bulan Maret 2018. IHT pada siklus II berjalan dengan lancar.Selama melakukan serangkaian kegiatan IHT, guru terlihat antuasias dalam menyimak, 
bertanya, dan mengumpulkan materi untuk menyusun RPP. Rekapitulasi hasil observasi guru dalam menyusun RPP pada siklus II dapat dilihat pada Tabel 5.

Tabel 5. Hasil Pengamatan Guru dalam Menyusun RPP Siklus II

\begin{tabular}{ccccc}
\hline TingkatKompetensi & Kategori & Frekuensi & $\%$ & Rata-Rata \\
\hline $85-100 \%$ & Sangatbaik & 16 & $44,44 \%$ & $2892: 36$ \\
$75-85 \%$ & Baik & 11 & $30,55 \%$ & $=80,35$ \\
$65-75 \%$ & Cukup & 7 & $19,44 \%$ & Kategori \\
$<65 \%$ & Kurang & 2 & $5,55 \%$ & Baik \\
\hline & JUMLAH & & 36 & $100 \%$ \\
\hline
\end{tabular}

Berdasarkan Tabel 5 dapat dilihat bahwa hasil observasi guru pada saat menyusun RPP pada siklus II, rata-rata yang diperoleh sebesar 80,35 dengan kategori baik. Rekapitulasi hasil penilaian kualitas RPP pada siklus II dapat dilihat pada tabel 6.

Tabel 6. Hasil Penilaian Kualitas RPP Siklus II

\begin{tabular}{ccccc}
\hline TingkatKompetensi & Kategori & Frekuensi & $\%$ & Rata-Rata \\
\hline $85-100 \%$ & Sangatbaik & 21 & $58,33 \%$ & $3042,5: 36$ \\
$75-85 \%$ & Baik & 13 & 36,11 & $=84,51$ \\
& & & $\%$ & \\
$65-75 \%$ & Cukup & 2 & $5,55 \%$ & Kategori \\
$<65 \%$ & Kurang & 0 & $0 \%$ & Cukup \\
\hline \multicolumn{2}{c}{ JUMLAH } & & 36 & \multicolumn{2}{c}{$100 \%$} \\
\hline
\end{tabular}

Berdasarkan Tabel 6 dapat dilihat bahwa rata-rata nilai kualitas RPP yang dibuat oleh guru pada siklus II sebesar 84,21 yang termasuk kategori baik.

Refleksi dilaksanakan setiap akhir siklus, dimaksudkan untuk mengetahui berbagai masalah yang muncul pada pelaksanaan tindakan siklus II. Kekurangan pada siklus I telah diperbaiki pada kegiatan IHT siklus II. Pada siklus II nilai kompetensi guru dalam menyusun Rencana Pelaksanaan Pembelajaran (RPP) peningkatan dari nilai siklus sebelumnya. Peningkatan kompetensi guru dalam menyusun RPP dapat dilihat pada Tabel 7 dan Gambar 1.

Tabel 7. Pencapaian Kompetensi Siklus II

\begin{tabular}{lccc}
\hline \multicolumn{1}{c}{ Keterangan } & Prasiklus & SiklusI & SiklusII \\
\hline Rata-rata Penilaian Kualitas RPP & 69,51 & 70,83 & 84,51 \\
Rata-rata Pengamatan Guru dalam Menyusun RPP & 69,65 & 74,79 & 80,35 \\
Rata-Rata Pencapaian Kompetensi & 69,58 & 72,81 & 83,13 \\
\hline
\end{tabular}




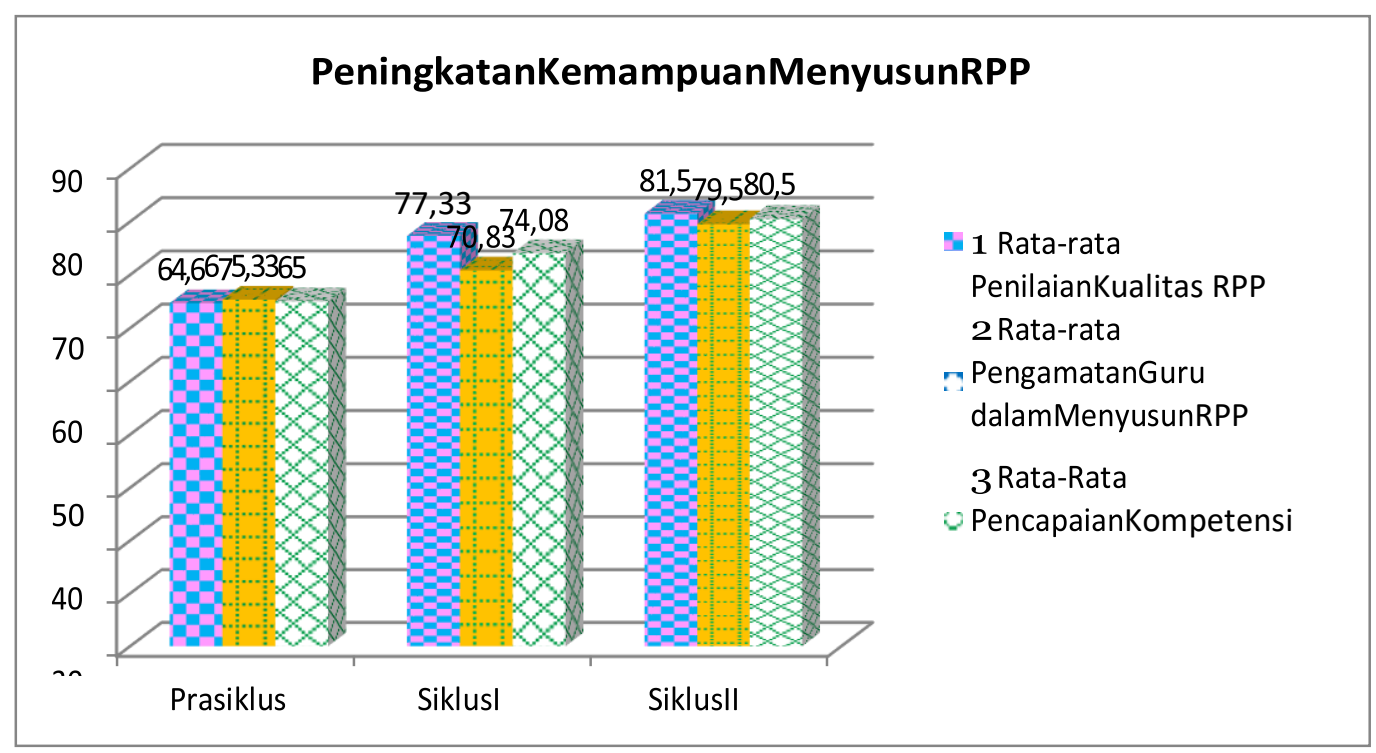

Gambar 1. Grafik Peningkatan Kompetensi Guru dalam Menyusun RPP

Berdasarkan Tabel 7 dan Gambar 1 dapat diketahui sebelum dilakukan tindakan (prasiklus) nilai kompetensi guru dalam menyusun RPP sebesar 65,50 dengan kategori cukup setelah tindakan siklus I mengalami peningkatan menjadi 73,25 dengan kategori cukup dan kembali mengalami peningkatan pada tindakan siklus II menjadi 82,25 dengan kategori baik.

\section{KESIMPULAN}

Melalui kegiatan IHT dapat meningkatkan kompetensi guru SMA Negeri 7 Kerinci dalam menyusun Rencana Pelaksanaan Pembelajaran (RPP). Dapat diketahui sebelum dilakukan tindakan (prasiklus) nilai kompetensi guru dalam menyusun RPP sebesar 65,50 dengan kategori cukup setelah tindakan siklus I mengalami peningkatan menjadi 73,25 dengan kategori cukup dan kembali mengalami peningkatan pada tindakan siklus II menjadi 82,25 dengan kategori baik.Langkah-langkah yang dilakukan dalam pelaksanaan IHT guna meningkatkan kompetensi guru SMA Negeri 7 Kerinci dalam menyusun Rencana Pelaksanaa Pembelajaran (RPP), yaitu: (a) menyampaikan pengumuman kepada guru tentang akan dilaksanakannya kegiatan IHT mengenai penyusunan RPP; (b) mempersiapkan materi bimbingan berupa pelaksanaan pembelajaran disertai simulasinya; (c) Mempersiapkan instrumen; (d) melaksanakan kegiatan IHT dengan tidak mengganggu kegiatan pembelajaran; dan e) melaksanakan pengamatan di kelas saat dilaksanakan kegiatan pembelajaran oleh guru.

\section{DAFTAR PUSTAKA}

Agustiani, D. (2018). Peningkatan kompetensi guru dalam menyusun RPP berbasis PPK (Penguatan Pendidikan Karakter) melaluiIn House Trainning di SDN KedungkendoKecamatan Candi KabupatenSidoar-jo. Jurnal Mitra Pendidikan, 5(4), 391-402.

Basri, H., \&Rusdiana, A. (2021). Manajemen Pendidikan \& Pelatihan. Bandung: CV PustakaSetia.

Faizin, F. (2020). Peningkatan Kompetensi Guru Dalam Menyusun Rencana Pelaksanaan Pembelajaran (Rpp) Melalui Kegiatan In House Training (Iht) Di Sd Negeri Surokidul 02 Kecamatan Bpagerbarang Kabupaten Tegal Semester Ii Tahun Pelajaran 2018/2019. DIALEKTIKA Jurnal Pemikiran dan Penelitian Pendidikan Dasar, 10(1), 322-335.

Jamaluddin, J. (2020). Peningkatan Kemampuan Guru Penyusunan RPP melaluiKegiatanIn House Training (IHT). Jurnal Kinerja Kependidikan (JKK), 2(3), 510-523.

Kamiludin, J. (2021). Pelaksanaan In House Training (Iht) Untuk Meningkatkan Kemampuan Guru Dalam Menyusun Rpp. Jurnal Pedagogiana, 8(89). 
Maolana, A. D. (2018). Peningkatan Kompetensi Guru Dalam Menyusun Rencana Pelaksanaan Pembelajaran MelaluiIn House Training. Jurnal Pendidikan Tambusai, 2(3), 953-969.

Sa'bani, F. (2017). Peningkatan Kompetensi Guru dalam Menyusun RPP Melalui Kegiatan Pelatihan pada MTs Muhammadiyah Wonosari. Jurnal Pendidikan Madrasah, Volume 2, Nomor 1, hlm. 13-22.

Subekti, B. D. (2019). Upaya Peningkatan Kompetensi Guru Dalam Pembuatan Skenario Pembelajaran Inovatif Melalui Iht (in House Training) Di Sd Negeri 1 Wirotaman. INVENTA: Jurnal Pendidikan Guru Sekolah Dasar, 3(1), 80-86. 